SCP66(3) Sept 2019 issue - VARIA

\title{
The economic practices of U.S. congregations: A review of current research and future opportunities
}

\author{
Peter MUNDEY \\ Indiana University, USA* \\ David KING \\ Indiana University, USA \\ Brad R FULTON \\ Indiana University, USA
}

\begin{abstract}
Religious congregations in the U.S. receive substantially more philanthropic contributions than any other category of organizations, yet little research has investigated how congregations receive, manage, and spend these donations. Although the economic practice of religious giving has been researched extensively, most of this research has focused on individuals or households, seeking to explain why people give to religious organizations. Relatively little research has examined the recipients of religious giving to determine how giving works within and affects these organizations. This review examines studies in the field of congregational finances, assesses available sources of data on congregations' economic practices, and concludes with recommendations for new avenues of research in this field.
\end{abstract}

${ }^{*}$ Corresponding author:

Peter Mundey, University of Oklahoma Health Sciences Center, 940 NE 13th Street, 4th Floor Nicholson Tower, Suite 4900, Oklahoma City OK 73104, USA

Email: peter-mundey@ouhsc.edu. 


\section{Keywords}

Religious giving, money, congregations, faith, religion, finances

\section{Résumé}

Les congrégations religieuses aux États-Unis reçoivent beaucoup plus de contributions philanthropiques que toute autre catégorie d'organisations, mais peu de recherches ont porté sur la façon dont les congrégations reçoivent, gèrent et dépensent ces dons. Bien que la pratique économique des dons religieux ait fait l'objet de recherches approfondies, la plupart de ces recherches se sont concentrées sur des individus ou des ménages, cherchant à expliquer pourquoi les gens donnent aux organisations religieuses. Relativement peu de recherches ont examiné les bénéficiaires de dons religieux pour déterminer comment les dons fonctionnent au sein de ces organismes et comment ils influent sur eux. Cette analyse examine les études dans le domaine des finances des congrégations, évalue les sources de données disponibles sur les pratiques économiques des congrégations, et conclut avec des recommandations pour de nouvelles pistes de recherche dans ce domaine.

\section{Mots-clés}

argent, congrégations, don religieux, finances, foi, religion

\section{Introduction}

The association between faith and finances has long been a subject of interest in social science, with scholars pursuing multiple avenues of inquiry over time. Classic studies reveal the link between religion and the spirit of capitalism (Weber, [1930] 2005) and economic inequality (Marx, [1844]1978). More recent studies explore how religion can motivate people to 'spend' 
their money by giving it away, as seen in a special issue of Review of Religious Research devoted to this topic (1994, vol. 36), and several subsequent studies (e.g., Chaves and Miller, 1999; Hoge et al., 1996; Hoge et al., 1998; Smith et al., 2008). While assessing individual-level motives and mechanisms for religious giving is one of the largest areas of research within the broader field of studies on faith and money (see Bekkers and Wiepking, 2007; Dempsey 2011; Lincoln et al., 2008; Steensland and Hemphill, 2016), our review takes an organizational-level approach. ${ }^{1}$ We focus on the broader economic practices of congregations - especially but not limited to religious giving - by reviewing existing research and outlining new lines of scholarly inquiry regarding how congregations receive, manage, and spend money.

The economic dynamics of congregational life are underexplored in social science research, although the broader topic of religious giving has received much attention. Within this field of research, the economic practices of congregations are most often explored in ways that focus on individuals rather than congregations (Finke et al., 2006; Lincoln et al., 2008; Steensland and Hemphill, 2016). We define congregations as churches, synagogues, mosques, and temples that meet regularly for religious worship/purposes (Fulton, forthcoming). Our review centers primarily on Christian congregations in the U.S. because they are the focus of the vast majority of research on congregations' economic practices. In addition, we focus mostly on religious giving since this topic dominates the extant research on congregations' economic practices. In the following sections, we identify major themes of existing research, available data sources, gaps in the literature, and suggested avenues for new research.

\section{Available data and studies on congregations' economic practices}


In the U.S., religious institutions (primarily congregations) are the largest recipient category for philanthropic giving - defined broadly as voluntary financial contributions. In 2017, giving to religious institutions represented 31 percent of all charitable giving in America, totaling \$127.37 billion dollars and more than doubling the amount of contributions made to education, the next largest charitable subsector (Indiana School of Philanthropy, 2018). Despite this designation as the leading philanthropic beneficiary, the financial state of congregations and their economic practices remain understudied. The few studies on the economic practices of congregations reveal that, when interviewed, congregational leaders express their fears over the financial solvency of their congregations, their discomfort with discussing faith and money, and the uncertain and evolving funding patterns of faith communities (Conway, 1999; Lilly Endowment, 2015; Smith et al., 2008). Additional research speaks to the financial challenges faced by many U.S. congregations (Gannon and Schwartz, 1992; Mead, 1998; Ronsvalle and Ronsvalle, 1996; Vallet and Zech, 1995; Wuthnow, 1997; Zech, 2000), especially in the wake of the Great Recession (Indiana School of Philanthropy, 2009, 2013; Roozen, 2011a). Studies also identify high levels of finance-related conflict in congregations (Roozen, 2011a, 2011b, 2016). Although this research points to a prevalence of fiscal problems encountered by congregations, detailed data on how congregations receive, manage, and spend their resources are either outdated, incomplete, or have limited generalizability, thus limiting knowledge about how these challenges are met.

Why has so little research investigated congregations' financial practices? Several constraints have restricted these investigations. First, precise estimates on giving to congregations are difficult to obtain, especially since many congregations do not make their financial data available to scholars and those that do often self-report these data - as is the case 
with the Yearbook of American and Canadian Churches - thus rendering 'apples to apples' comparisons difficult. Second, studying congregations often requires identifying a key informant at each congregation surveyed - typically clergy, a staff member, or lay leader - and conducting these interviews is often more challenging than surveying a general sample of individuals (Frenk et al., 2011). Furthermore, these key informants are not always capable of or comfortable with answering questions about congregational finances. Third, social scientists lack a comprehensive list of congregations from which to draw a nationally representative sample, and the lists that are available (e.g., the U.S. Religion Census, the American Church List-Info USA) tend to underrepresent smaller and non-denominational congregations. One such list, the Yearbook of American and Canadian Churches, aggregated giving patterns of many denominations, but ceased publication in 2012. The Association of Statisticians of American Religious Bodies and Lake Institute on Faith and Giving at the Indiana University Lilly Family School of Philanthropy recently entered into an agreement with the National Council of Churches to begin collecting data and resume publication of the Yearbook. Once repopulated with data from reporting denominations, the Yearbook will again serve as helpful data source on religious giving patterns, but it has historically favored more established denominations and thus lacked comprehensive, representative, and comparable data on giving to congregations across all denominations and faith traditions.

Other scholarly data sources exhibit comparable limitations. Giving USA: The Annual Report on Philanthropy includes an annual estimate for religious giving in America, but relies on the outdated 1986 national survey commissioned by Independent Sector to provide a baseline from which annual estimates are updated (Indiana University School of Philanthropy, 2016). Indiana University's Congregational Economic Impact Study (CEIS) of 2009 (N=1,525) 
primarily surveyed mainline Protestant congregations and focused explicitly on issues related to the Great Recession rather than on congregations' economic practices as a whole (Indiana School of Philanthropy, 2009). The 2013 wave of the CEIS $(\mathrm{N}=3,103)$ also surveyed primarily mainline Protestant congregations (about two-thirds of the sample) and evangelical Protestant congregations (nearly one-fourth of the sample), although it did include some Catholic, black Protestant, and Jewish congregations (Indiana School of Philanthropy, 2013). Jon and Sylvia Ronsvalle's most recent 'State of Church Giving' report, now in its $28^{\text {th }}$ edition, provides helpful longitudinal data on church giving from 1921-2016 (Ronsvalle and Ronsvalle, 2018). However, like the Yearbook of American and Canadian Churches, these data are largely dependent on inconsistent denominational-self reporting and are not based on a nationally representative sample of U.S. congregations.

Similar constraints are present in data sources intended for non-academic audiences (such as pastors and lay leaders). For example, the 'State of the Plate Survey' (Kluth, 2016), which collected data on giving to congregations in the U.S., Australia, and Canada from 2010-2016, is not nationally representative. Leadership Network, a church consulting firm, has conducted research on the economic practices of U.S. congregations - including budgeting, staffing, and salary trends - but this research focuses on megachurches (Bird, 2013, 2016). The Evangelical Council on Financial Accountability (ECFA) published its $7^{\text {th }}$ annual 'State of Giving Report' in 2016, but these data primarily sample large evangelical, nondenominational congregations, in addition to parachurch ministries (Evangelical Council on Financial Accountability, 2016).

Another challenge facing scholars of congregational finances is that comprehensive studies in the field are outdated. Research on congregational finances peaked in the 1990s. For example, the 1993 American Congregational Giving Study (ACGS) collected data on 125 
congregations each from Catholic, PCUSA, Southern Baptist, Evangelical Lutheran, and Assemblies of God denominations, resulting in a final sample of 625 congregations. This study included both a lay questionnaire and a congregational profile completed by a pastor or congregation leader. Numerous studies have analyzed data from the ACGS (e.g., Finke et al., 2006; Hoge et al., 1996; Hoge et al., 1998; Olson and Perl, 2001, 2005; Perl and Olson, 2000). Another noteworthy comprehensive study from this period is Independent Sector's 1992 national study of U.S. congregations, focusing on issues related to congregational finances and community service activities. The primary investigators used the Yellow Pages (phone books) to create a sample frame of 257,648 congregations from which they randomly selected 3,779 congregations to participate (Hodgkinson and Weitzman, 1992; Hodgkinson, 1999). A final important congregational finance study conducted in the 1990s was Wuthnow's (1997) analysis of the financial struggles of congregations. Wuthnow based his conclusions on quantitative data from the Economic Values Survey (1992), which surveyed approximately 2,000 members of the U.S. labor force. He also drew on qualitative data from lay and pastoral interviews with Catholics and Protestants in 60 congregations across the country, content analysis of more than 200 sermons on stewardship, and content analysis of congregational financial documents. ${ }^{2}$

More recently, the Science of Generosity Study (2010) included some questions on congregational finances (Mundey, 2015; Snell Herzog and Price, 2016; Starks and Smith, n.d.), but this topic was not its primary focus. ${ }^{3}$ High-quality contemporary datasets on congregations also exist, but, again, they do not focus primarily on congregational finances. Especially noteworthy are the National Congregations Study (NCS, 1998, 2006-07, 2012, and 2018; see e.g., Chaves, 2004, 2013; Chaves \& Eagle, 2015), the U.S. Congregational Life Survey (UCLS, 2001 and 2008-2009; see e.g., Woolever and Bruce, 2002, 2010), and the Faith Communities 
Today Study (FACT, 2000, 2005, 2008, 2010, and 2015; see e.g., Roozen, 2011b, 2016). Taken as a whole, these studies provide basic information about congregations' financial health, budgets, income, debt, financial conflict, capital campaigns, and expenditures. Although these studies cover a wide range of topics - and the NCS and USCLS benefit from using a hypernetwork sample frame to produce a nationally representative sample of congregations - they do not provide in-depth information on the economic practices of congregations. Furthermore, the UCLS and the FACT have relatively low response rates for some waves. Nevertheless, these studies serve as a launching point for more in-depth research on congregational finances and provide some useful current trend data. ${ }^{4}$

For example, longitudinal data from the NCS (Chaves 2004; Chaves et al., 2014; Chaves and Eagle, 2015) reveal that financial resources are coalescing in the very largest congregations. While a majority of congregations in the U.S. are small in terms of members, and have small budgets, most Americans who attend religious services join congregations with mega-sized budgets and attendee rosters. The 2012 (Chaves and Eagle, 2015:5) wave of the NCS found that '...the average congregation had only 70 regular participants, counting both adults and children, and an annual budget of $\$ 85,000$. At the same time, the average attendee worshipped in a congregation with about 400 regular participants and a budget of $\$ 450,000$.' In 2012, about 76 percent of U.S. congregations had a 'formal written budget' and the median annual budget was $\$ 85,000$. Sixty-one percent reported having an endowment, savings account, or reserve fund; the median amount in these funds was $\$ 33,000$. About 26 percent of congregations were in debt, and the median amount of debt was $\$ 170,000$. The total median annual income was $\$ 95,000$, and the median annual income from individual contributions was $\$ 84,000$, indicating that the vast majority of congregations' income comes from individuals. However, other sources of 
congregational income are not uncommon. Twenty-two percent of congregations received income from selling or renting property (Chaves and Eagle, 2015).

In spite of debt and lingering fiscal strain from the Great Recession, some U.S. congregations seek to serve as a source of financial support for other organizations. In 2012, about 19 percent of U.S. congregations sent money directly to congregations outside the U.S., and about 80 percent of congregations affiliated with a denomination sent money to their denominations. The median amount sent to denominations from denominationally affiliated congregations was $\$ 7,500$; this amount, as a percentage of congregational income, has declined from 1998 to 2012 (Chaves and Eagle, 2015).

Beyond the NCS data, other studies reveal how congregations receive revenue from endowments (Hoge and Mead, 1999) and private foundations (Lindsay and Wuthnow, 2010). Additional research provides in-depth information on what congregations fund, including social service provision (Ammerman, 2005; Chaves and Tsitsos, 2001; Cnaan, 2002; Fulton, 2016; Scharffs, 2007), community organizing and civic engagement (Wood and Fulton, 2015; Fulton 2017), international missions and aid (Hudson Institute, 2016; Wuthnow, 2009), and religious schools (Greeley et al., 1976; Harris 1996, 1999; Ruger, 1999). Targeted studies on religious giving within particular groups or denominations have resulted in data on giving to black Protestant churches (Barnes 2013; Pressley, 1995; Pressley and Collier, 1999), Muslim mosques (Bagby et al., 2001; Bagby, 2012), Orthodox parishes (Krindatch, 2015), Presbyterian congregations (Krohn, 1995; Lunn et al., 2001; Nemeth and Luidens, 1994), Reformed churches (Luidens and Nemeth, 1994), Jewish synagogues (Cohen, 2004; Cohen et al., 2011; Cohen and Landres, 2014), Mormon temples (Curtis et al., 2014, 2015; Dahl and Ransom, 1999), Baptist churches (Hull et al., 2010), the Evangelical Lutheran Church (Inskeep, 1994; Brewer et al., 
2006), and Catholic parishes (Hoge and Augustyn, 1997; Miller et al., 2001, 2002; Notarantonio and Quigley, 2009; Rexhausen and Cieslak, 1994; Starks and Smith, n.d.; Zech, 2000; Zech et al., 2017, esp. Chapter 6). In addition, the Center for Applied Research in the Apostolate (CARA), has conducted a substantial amount of research on Catholic giving. For example, the U.S. Parish Life Study (2010, 2011-2012; Center for Applied Research in the Apostolate, 2015) includes questions on this topic, and 'The CARA Report' contains numerous research reports on "religious giving and stewardship" (Center for Applied Research in the Apostolate, 2019). Although the studies highlighted above provide helpful tradition-specific findings about religious giving, they lack the ability to compare among religious groups.

In response to this gap in knowledge, the National Study of Congregations' Economic Practices (NSCEP) recently completed a nationally representative survey of congregations that collected extensive data on how congregations receive, manage, and spend their financial resources (Fulton and King, 2018). Data from this survey will provide of broad assessment of the financial health of U.S. congregations and will enable scholars to compare the economic practices of congregations across religious traditions. Subsequent phases of the NSCEP will include in-depth interviews of congregational leaders and ethnographic observations of congregations to gain a deeper understanding of congregations' theological, cultural, and practical orientations toward money. Overall, the NSCEP is among the first studies of this scope and scale to provide a comprehensive assessment of the finances and economic practices of congregations.

\section{Major themes in the literature on congregational finances}

Having identified and assessed available data sources and studies on congregational finances, we now turn to some of the key findings from this literature. First, research consistently indicates 
that Protestants tend to give more than Catholics. Among Protestants, evangelicals give more than mainliners; theologically conservative congregations thus generally receive more contributions from their members than theologically liberal congregations (Chaves and Eagle, 2015; Dempsey, 2011; Lincoln et al., 2008; Steensland and Hemphill, 2016).

Another major theme in the literature draws on religious economies theory, which suggests that belonging to a 'winning' congregation with large market share and little competition from other congregations reduces per capita religious giving. Conversely, per capita religious giving increases in congregations with small market share and high levels of competition. When congregations appear to be doing well, there is less perceived need for donations on the part of congregants, whereas when congregations are struggling, or competing for members with other congregations, individual congregants feel more compelled to give larger sums (see e.g., Hull et al., 2010; Perl and Olson, 2000).

Studies have also assessed the impact of congregational cultures of money on giving (Miller, 1999; Mundey et al., 2011). Of particular note are cultures emphasizing giving to fund the broader mission of the congregation versus giving to maintain congregational programming. This mission vs. maintenance framing of religious giving has also been termed as 'Live the Vision' vs. 'Pay the Bills' cultures of congregational giving (Smith et al., 2008). In congregations with a Pay the Bills culture, giving is framed as an obligation for parishioners to keep the congregation financially afloat and to support its basic programming: paying the pastors, keeping the heat and lights on, and running activities. The alternative congregational culture, Live the Vision, frames giving as something parishioners do as part of their religious identity rather than a practical response to a budget necessity. Live the Vision giving is framed as performing an act of worship, growing as a person of faith, and participating in the broader 
mission of the congregation in the world and local community. Although both cultures of money can produce generous givers, the Pay the Bills culture is more tenuous and less stable over the long-term. Conversely, a Live the Vision culture appears to attract a broader base of givers who continue to give over time, thus increasing levels of congregational giving (Mundey et al., 2011; Smith et al., 2008; Starks and Smith, n.d.).

Another core finding of numerous studies on congregational giving is some variant of the Pareto Principle (or $80 / 20$ rule). In short, a small cohort of givers provides the vast majority of congregational funds, while the rest of the congregation gives very little, thus 'free-riding' (Brewer et al., 2006; Hoge, 1994; Hoge and Yang, 1994; Hull et al., 2010; Iannaccone, 1992, 1997; Zaleski and Zech, 1992). This principle appears to be particularly evident in larger congregations. Individuals in smaller congregations tend to give more per capita in absolute dollars to their religious organizations than do those in larger congregations; as congregational size increases so does free riding (Chaves and Eagle, 2015).

Whereas cultures of free-riding decrease per capita religious giving, cultures of commitment appear to increase giving, as evidenced by research showing that 'strict church' cultures (Iannaccone, 1994) with high degrees of exclusivity and high demands on their members - often found in evangelical or fundamentalist religious traditions - tend to have high-giving memberships that discourage free-riders (Finke et al., 2006; Olson and Perl, 2001, 2005; Rosborough, 2015; Scheitle and Finke, 2008; Whitehead, 2010). Expecting that members tithegiving 10 percent of their income to the church - is a notable measure of strictness (Finke et al., 2006). Members of theologically conservative congregations are more likely to tithe than their theologically liberal counterparts, as is also the case with frequent service attenders as opposed to infrequent attenders (Smith et al., 2008). Although tithing is a staple of congregational 
cultures that result in high levels of generosity, very few Christians in the U.S. tithe a full 10 percent of their income (Smith et al., 2008; James and Jones, 2011), and only 2.7\% of all Americans tithe (Smith and Davidson, 2014). Further, although tithing requirements have been found to increase both overall giving to congregations (Rosborough, 2015) and household giving within parishes (Miller et al., 2002), they have also been found to decrease congregation membership rolls (Rosborough, 2015).

As a form of planned (rather than impromptu) giving, the association between tithing and increased giving is indicative of the success of planned giving strategies in increasing contributions. For example, pledge systems in which members commit in advance to give a certain amount of money during the year have been shown to increase giving (Chaves, 1999; Hoge, 1994; Inskeep, 1994). Whether tithing or giving some other pre-determined amount, cultures of planned giving encourage congregants to give first and spend second, thus making giving a priority rather than an afterthought (Smith et al., 2008).

Tithing requirements are often met with resistance by church-going Americans, which illustrates how giving is a sensitive and often unsettling topic for congregants and pastors alike (Smith et al., 2008). The prevalence of this unease is another central finding in the field. As 'reluctant stewards' of congregational finances (Conway, 1992, 1999, 2002), clergy often feel uncomfortable with the fundraising aspect of their jobs (Smith et al., 2008; Wuthnow, 1997). Congregants regularly have negative feelings as well, expressing guilt about their levels of giving. However, they generally do not feel guilty enough to increase their giving, resulting in a 'comfortable guilt' (Smith et al., 2008: 110). Consequently, what emerges in many congregations is a culture of fiscal avoidance by both clergy and congregants, who prefer not to confront an uncomfortable and perhaps even toxic issue within their congregations. This tendency to avoid 
and ignore money matters contributes to worsening fiscal states in many congregations

(Wuthnow, 1997). Conversely, research suggests that congregations that tackle money matters head on, specifically through stewardship/giving programs and stewardship committees, have successful fundraising efforts (Miller et al., 2002; Rexhausen and Cieslak, 1994).

Other studies show that congregational stewardship initiatives may fail due to scandals and cultures of distrust, especially distrust of religious leaders. Research shows that the Catholic clergy sexual misconduct scandal corresponded with a decrease in Catholic giving (Bottan and Perez-Truglia, 2015; Hungerman, 2013). The decrease, however, appears to be primarily a decrease in giving to dioceses and to the Catholic church in general, but not a decrease in giving to local parishes (Gray and Perl, 2006). Conversely, increased giving is associated with congregational cultures marked not only by trustworthy leaders, but also clergy who demonstrate 'emotional and social competencies' (Boyatzis et al., 2010:192). Congregants who have high levels of satisfaction with religious programming (Notarantonio and Quigley, 2009) and the congregational budget (Peifer, 2010) are also more likely to give. This evidence speaks to another important theme in the literature: the quality of programming, leadership, and community life in congregations impacts giving. Parishes that better address the needs of their parishioners through their programming receive higher donations (Cieslak, 1984), and congregational worship experiences that produce positive emotions among worshipers result in higher donations (Corcoran, 2015). Positive feelings among congregants can also be generated by recognizing donors for their gifts (Notarantonio and Quigley, 2009), thus creating a 'warm glow' (Andreoni, 1990) effect on the giver that increases giving.

More generally, high levels of social capital - such as supportive relationships among members of a congregation who embody strong group solidarity - result in higher giving 
(Freeburg, 2016; Peifer, 2010). Similarly, congregations with high participation or involvement in religious activities experience greater giving (Clain and Zech, 1999; Finke et al., 2006; Forbes and Zampelli, 2013; Whitney, 2010), suggesting a high degree of commitment to the communal life of the congregation.

\section{Gaps in the literature and areas for future research}

Having reviewed the major themes revealed in the existing literature on congregational finances, next we turn our attention to gaps in this literature and areas for future research, beginning with the gap upon which this review is premised. Although our review has drawn attention to studies emphasizing congregational giving, the field of religious giving as a whole heavily emphasizes individual and household givers. The research is thus skewed towards focusing on religious individuals rather than religious organizations. New studies are necessary to understand religious giving from a recipient-side perspective in order to better assess how and why some congregations receive more donations than others. Also missing are ongoing longitudinal studies on congregational giving. Although some research is being done by Jon and Sylvia Ronsvalle at Empty Tomb, Inc, the Yearbook of American and Canadian Churches, the Evangelical Council for Financial Accountability, and the State of the Plate Survey, these data are limited in generalizability and scope, and therefore are insufficient for scholars seeking to track change over time.

The giving-centric nature of the research on congregations' finances also underexplores broader issues of faith and finances. Issues related to congregational spending, expenses, disbursements, and financial conflict are understudied. Moreover, while some studies investigate the link between faith and the workplace (Miller, 2006; Vaidyanathan, 2013; Wuthnow, 1994, 
1995), and others examine how faith relates to consumerism and materialism (Mundey, 2015, 2017; Wuthnow, 1994), questions remain unexplored regarding whether and how congregations are engaging these issues. Scholars should explore in greater depth how congregations talk to congregants about their consumer spending and broader engagement with consumer culture. Notwithstanding Burkinshaw (2000), we know little about how congregations seek to instill effective money management practices among their congregants, provide financial counseling services, or implement financial counseling curricula. Thirty-one percent of congregations in 2012 reported that they had organized within the past year an event to 'discuss/learn about managing personal finances' (Chaves and Eagle, 2015: 51), but it is unclear what these programs address, how effective they are, and how they relate to congregations' overall fiscal health and broader economic culture.

Financial decision-making processes in congregations are also underexplored. Unanswered questions include: How democratic are money management processes? How are budgets assembled? Which individuals and committees are significantly involved in financial decisions? While we know that 66 percent of U.S. congregations in 2012 organized an event within the past year 'to discuss how to improve the management of [their] congregation's money' (Chaves and Eagle, 2015), there is little research on best practices for these types of meetings and what type of impact they make on congregational finances.

Additionally, social science researchers and religious practitioners alike would benefit from more qualitative research on congregations' economic practices. The vast majority of the research on congregational finances is quantitative in nature, typically using survey-based research methodologies to measure the variables most likely to predict giving. While notable ethnographic and interview-based studies on congregational giving exist (e.g., Curtis et al., 2014; 
Miller, 1999; Mundey et al., 2011; Smith et al., 2008; Vaidyanathan and Snell, 2011; Wuthnow, 1994, 1997), these are the exceptions to the quantitative rule. Ethnographic studies of congregational finances have limited generalizability, but provide valuable 'on the ground' accounts of economic life in congregations, assessing how the content and rituals of worship services likely impact giving patterns, and investigating the different ways money is made sacred in various congregational cultures (see e.g., Miller 1999; Mundey et al., 2011).

While ethnographic research has been especially helpful in identifying congregational cultures of money, this research has stalled at discussions of 'Pay the Bills' cultures vs. 'Live the Vision' cultures. Future studies should push toward evolving the congregational culture literature to explore the nuances, varieties, and alternatives to these cultures. New research, for example, could concentrate on distinctive cultures of money within particular religious traditions (e.g., conservative Protestants, black Protestants, Catholics) in order to explain differences in congregational giving among them. While existing studies identify cultures of prosperity (i.e., the prosperity gospel) within congregations (see, e.g., Bowler, 2013; Harrison, 2005; Mundey, 2017), little is known about other fiscal cultures in America's places of worship. ${ }^{5}$

Another emerging, but still understudied, topic in the literature on congregational giving is innovative fundraising methods beyond traditional 'passing the plate' approaches—such as rent from space sharing (Numrich, 2016) and entrepreneurial ventures on congregation property (e.g., coffee shops). Research on emerging collection methods - including online giving and electronic giving kiosks - is also lacking, notwithstanding a few exceptions (Bird, 2014; Copeland, 2015; Gray et al., 2013; Throop, 2007). Studies analyzing e-giving are necessary to ascertain how congregations are adapting (or not adapting) to the increasing normativity of digitized financial transactions. Research on this topic may be particularly helpful in revealing ways to encourage 
giving among younger tech-savvy congregants. At present, only a few studies examine the socialization of the next generation of religious givers (Ottoni Wilhelm et al., 2008; Plotinsky, 1995; Snell Herzog and Mitchell, 2016). More research is needed to better understand how congregations can transmit norms of religious giving to the next generation.

\section{Concluding thoughts}

Although research on individual giving has burgeoned, congregation-centric research on giving is lacking. This lack of attention to the organizational level of giving is problematic because of the important role congregations play in providing spiritual, economic, and material support to many segments of society (Grim and Grim, 2016; Partners for Sacred Places, n.d.). Thus, knowing the financial health of congregations, and the resources they need to carry out their work, is critical. Moving forward, research on the economic practices of U.S. congregations would benefit from multi-level studies that combine survey and interview research with ethnography. Such studies could provide scholars and practitioners with broader knowledge about how congregations receive, manage, and spend their financial resources, as well as a deeper understanding of congregations' theological, cultural, and practical orientations toward money.

\section{Acknowledgement}

We are grateful to Elisabeth Andrews for providing editorial assistance.

\section{Funding}

Special thanks to the Lilly Endowment, Inc. for funding this research.

\section{Corresponding author}

Peter Mundey, University of Oklahoma Health Sciences Center, 940 NE 13th Street, 4th Floor Nicholson Tower, Suite 4900, Oklahoma City OK 73104, USA 
Email: peter-mundey@ouhsc.edu.

${ }^{1}$ For an example of an organizational approach to examining charitable giving in the nonprofit sector more broadly see Paxton (forthcoming).

${ }^{2}$ Another notable 1990s study with some questions on congregational finances is the God and Society in North America Survey (1996).

${ }^{3}$ Though not focusing on religion and finances, the Faith Matters Survey (2011) is another more recent study that includes a few questions on religious giving.

${ }^{4}$ These studies and many of the other congregational surveys mentioned in this article can be accessed at: http://www.thearda.com/archive

${ }^{5}$ Special thanks to Nancy Ammerman for pointing out the need for new research in this area. 


\section{References}

Ammerman NT (2005) Pillars of Faith: American Congregations and Their Partners. Berkley: University of California Press.

Andreoni J (1990) Impure altruism and donations to public goods: A theory of warm glow giving. The Economic Journal 100(401): 464-477.

Bagby I, Perl PM and Froehle BT (2001) The mosque in America: A national portrait. Report, Council on America-Islamic Relations, Washington, DC.

Bagby I (2012) The American mosque 2011: Basic characteristics of the American mosque, attitudes of mosque leaders. Report no. 1 from the US Mosque Study 2011, Council on American-Islamic Relations, Washington, DC.

Barnes SL (2013) Black church giving: An analysis of ideological, programmatic, and denominational effects. SAGE Open 3(2): 1-11.

Bekkers R and Wiepking P (2007) Generosity and philanthropy: A literature review. Report, Science of Generosity Project, Notre Dame, IN.

Bird W (2013) The economic outlook of very large churches. Report, Leadership Network, Dallas, TX.

Bird W (2014) New innovations in online giving. Report, Leadership Network, Dallas, TX.

Bird W (2016) 12 salary trends every church leader should know: 2016 large church salary study. Report, Leadership Network, Dallas, TX.

Bottan NL and Perez-Truglia R (2015) Losing my religion: The effects of religious scandals on religious participation and charitable giving. Journal of Public Economics 129: 106-119.

Bowler K (2013) Blessed: A History of the American Prosperity Gospel. New York: Oxford University Press.

Boyatzis RE, Brizz T and Goodwin LN (2010) The effect of religious leaders' emotional and social competencies on improving parish vibrancy. Journal of Leadership \& Organizational Studies 18(2): 192-206.

Brewer SM, Jozefowicz JJ and Stonebraker RJ (2006) Religious free riders: The impact of market share. Journal for the Scientific Study of Religion 45(3): 389-396.

Burkinshaw R (2000) Money matters: The phenomenon of financial counselor Larry Burkett and Christian financial concepts. In: Eskridge L and Noll MA (eds) More Money, More Ministry: Evangelicals in Recent North American History. Grand Rapids: William B. Eerdmans Publishing Company, 311-350.

Center for Applied Research in the Apostolate (2015) U.S. Parish Life Study. Available at: https://cara.georgetown.edu/CARAServices/emergingmodels.html (accessed $22 \mathrm{March}$ 2019).

Center for Applied Research in the Apostolate (2019) The CARA Report. Available at: https://cara.georgetown.edu/publication/the-cara-report/subject-index/ (accessed 22 March 2019). 
Chaves M (1999). Financing American Religion. In: Chaves M and Miller S (eds) Financing American Religion. Walnut Creek: Alta Mira, 169-187.

Chaves M (2004) Congregations in America. Cambridge: Harvard University Press.

Chaves M (2013) American Religion: Contemporary Trends. Princeton: Princeton University Press.

Chaves M and Miller SL eds (1999). Financing American Religion. Walnut Creek: Alta Mira

Chaves M and Tsitsos W (2001) Congregations and social services: What they do, how they do it, and with whom. Nonprofit and Voluntary Sector Quarterly 30(4): 660-683.

Chaves M, Anderson S and Eagle A (2014) National Congregations Study: Cumulative datafile and codebook. Report, Duke University, Durham, NC.

Chaves M and Eagle A (2015) Religious congregations in $21^{\text {st }}$ century America: National Congregations Study. Report, Duke University, Durham, NC.

Cieslak MJ (1984) Parish responsiveness and parishioner commitment. Review of Religious Research 36(2): 132-147.

Clain SH and Zech CE (1999) A household production analysis of religious and charitable activity. American Journal of Economics and Sociology 58(4): 923-946.

Cnaan RA (2002) The Invisible Caring Hand: American Congregations and the Provision of Welfare. New York: New York University Press.

Cohen SM (2004) Philanthropic giving among American Jews: Contributions to federation, Jewish and non-Jewish causes. Report no. 4, United Jewish Communities Report Series on the National Jewish Population Survey 2000-01, New York, NY.

Cohen SM, Hoffman LA, Ament J and Miller R (2011) Conservative \& reform congregations in the United States today: Findings from the FACT-Synagogue 3000 Survey of 2010. Report, Berman Jewish Policy Archive, New York, NY.

Cohen SM and Landres JS (2014) Connected to give: Synagogues and movements, findings from the National Study of American Jewish Giving. Report, Jumpstart, Los Angeles, CA.

Conway D (1992) The reluctant steward: A report and commentary on the stewardship development study. Report, Christian Theological Seminary and Saint Meinrad Seminary, Indianapolis, IN and St. Meinrad, IN.

Conway D (1999) Clergy as reluctant stewards of congregational resources. In: Chaves M and Miller S (eds) Financing American Religion. Walnut Creek: Alta Mira, 95-101.

Conway D (2002) The reluctant steward revisited: Preparing pastors for administrative and financial duties. Report, Saint Meinrad Seminary, St. Meinrad, IN.

Copeland AJ (2015) Crowdfunding a new church - a multimodal analysis of faith-related giving rhetoric on Indiegogo. Heidelberg Journal of Religions on the Internet 9: 1-18.

Corcoran KE (2015) Thinkers and feelers: Emotion and giving. Social Science Research 52: 686700. 
Curtis D, Cnaan RA and Evans V (2014) Motivating Mormons: An analysis of what motivates members of the Church of Jesus Christ of Latter-day Saints to volunteer and donate. Nonprofit Management \& Leadership 25(2): 131-130.

Curtis D, Evans V and Cnaan RA (2015) Charitable practices of Latter-day Saints. Nonprofit and Voluntary Sector Quarterly 44(1): 146-162.

Dahl GB and Ransom MR (1999) Does where you stand depend on where you sit? Tithing donations and self-serving beliefs. The American Economic Review 89(4): 703-727.

Dempsey PR (2011) Review of recent literature on faith and giving. Report, Lake Institute on Faith and Giving, Indianapolis, IN.

Evangelical Council on Financial Accountability (2016) State of giving report. Report, Evangelical Council on Financial Accountability, Winchester, VA.

Faith Matters Survey (2011). Available at:

http://www.thearda.com/Archive/Files/Descriptions/FTHMAT11.asp (accessed 26 March 2019).

Finke R, Bahr M and Scheitle CP (2006) Toward explaining congregational giving. Social Science Research 35(3): 620-641.

Forbes KF and Zampelli EM (2013) The impacts of religion, political ideology, and social capital on religious and secular giving: Evidence from the 2006 Social Capital Community Survey. Applied Economics 45(17): 2481-2490.

Freeburg D (2016) Trust and tithing: The relationships between religious social capital and church financial giving. Journal of Contemporary Ministry 2: 39-55.

Frenk SM, Anderson SL, Chaves M and Martin N (2011) Assessing the validity of key informant reports about congregations' social composition. Sociology of Religion 72(1): 78-90.

Fulton BR (forthcoming) Religious organizations: Crosscutting the nonprofit sector. In: The Nonprofit Sector: A Research Handbook, $3^{\text {rd }}$ edition (eds) Powell WW and Bromley P. Stanford: Stanford University Press.

Fulton BR (2017) Fostering Muslim civic engagement through faith-based community organizing. Journal of Muslim Philanthropy and Civil Society 1(1): 23-39.

Fulton BR (2016) Trends in addressing social needs: A longitudinal study of congregation-based service provision and political participation. Religions 7(5): 51-67.

Fulton BR and King PK (2018) National Study of Congregations' Economic Practices: Survey data file. Bloomington: Indiana University.

Gannon TM and Schwartz DF (1992) Church finances in crisis. Social Compass 39(1): 111-120.

God and Society in North American Survey (1996). Available at: http://www.thearda.com/Archive/Files/Descriptions/QUEENS.asp (accessed 25 March 2019). 
Gray MM and Perl PM (2006) Catholic Reactions to the News of Sexual Abuse Cases Involving Catholic Clergy. Working Paper 8, Center for Applied Research in the Apostolate (CARA), Washington, DC.

Gray MM, Gaunt TP and Saunders C (2013) U.S. Catholic online giving. Report, Center for Applied Research in the Apostolate (CARA), Washington, DC.

Greeley A, McCourt K and McCready W (1976) Catholic Schools in a Declining Church. Kansas City: Sheed and Ward.

Grim BJ and Grim ME (2016) The Socio-economic contribution of religion to American society: An empirical analysis. Interdisciplinary Journal of Research on Religion 12(3): 2-31.

Harris JC (1996) The Cost of Catholic Parishes and Schools. Kansas City: Sheed and Ward.

Harris JC (1999) Financing Catholic elementary schools. In: Chaves M and Miller SL (eds) Financing American Religion. Lanham: AltaMira, 105-111.

Harrison MF (2005) Righteous Riches: The Word of Faith Movement in Contemporary African American Religion. New York: Oxford University Press.

Hodgkinson VA and Weitzman MS (1992) From Belief to Commitment: The Community Service Activities and Finances of Religious Congregations in the United States. Washington, DC: Independent Sector.

Hodgkinson VA (1999) Financing religious congregations: A national view. In: Chaves M and Miller SL (eds) Financing American Religion. Lanham: AltaMira, 79-86.

Hoge DR (1994) Introduction: The problem of understanding church giving. Review of Religious Research 36(2): 101-110.

Hoge DR and Yang F (1994) Determinants of religious giving in American denominations: Data from two nationwide surveys. Review of Religious Research 36(2): 123-148.

Hoge DR, Zech C, McNamara P and Donahue MJ (1996) Money Matters: Personal Giving in American Churches. Louisville: Westminster John Knox Press.

Hoge DR and Augustyn B (1997) Financial contributions to Catholic parishes: A nationwide study of determinants. Review of Religious Research 39(1): 46-60.

Hoge DR, McNamara P and Zech C (1998) Plain Talk about Churches and Money. Durham: Alban Institute.

Hoge DR and Mead LB (1999) Endowed congregations. In: Chaves M and Miller SL (eds) Financing American Religion. Lanham: AltaMira, 87-94.

Hudson Institute (2016) The Index of Global Philanthropy and Remittances. Report, Hudson Institute, Inc., Washington DC.

Hull BB, Hull BB and Lipford J (2010) Free riding, market structure, and church member donations in South Carolina. Review of Religious Research 52(2): 172-187.

Hungerman D (2013) Substitution and stigma: Evidence on religious markets from the Catholic sex abuse scandal. American Economic Journal: Economic Policy 5(3): 227-253. 
Iannaccone L (1992) Sacrifice and stigma: Reducing free-riding in cults, communes, and other collectives. Journal of Political Economy 100(2): 271-297.

Iannaccone L (1994) Why strict churches are strong. American Journal of Sociology 99(5): 11801211.

Iannaccone L (1997) Skewness explained: A rational choice model of religious giving. Journal for the Scientific Study of Religion 26(2): 141-157.

Indiana School of Philanthropy (2009) The 2009 congregational economic impact study. Report, IU School of Philanthropy, Indianapolis, IN.

Indiana School of Philanthropy (2013) The 2013 congregational economic impact study. Report, IU School of Philanthropy, Indianapolis, IN.

Indiana School of Philanthropy (2018) Giving USA: The Annual Report on Philanthropy for the Year 2015. Report, Giving USA Foundation, Chicago, IL.

Inskeep KW (1994) Giving trends in the Evangelical Lutheran church in America. Review of Religious Research 36(2): 238-244.

James RN and Jones KS (2011) Tithing and religious charitable giving in America. Applied Economics 43(19): 2441-2450.

Kluth B (2016) State of the plate report. Report, Tithely: Innovative Church Giving, Los Angeles, CA.

Krindatch AD (2015) Exploring Orthodox generosity: Giving in US Orthodox parishes. Report, Assembly of Canonical Orthodox Bishops of the United States of America, South Bound Brook, NJ.

Krohn GA (1995) The receipts and benevolences of Presbyterian congregations, 1973-1988. Journal for the Scientific Study of Religion 43(1): 17-34.

Lilly Endowment (2015) Economic challenges facing pastoral leaders. Report, Lilly Endowment, Inc., Indianapolis, IN.

Lincoln R, Morrissey CA and Mundey P (2008) Religious giving: A literature review. Report, Science of Generosity Project, Notre Dame, IN.

Lindsay DM and Wuthnow R (2010) Financing faith: Religion and strategic philanthropy. Journal for the Scientific Study of Religion 49(1): 87-111.

Luidens DA and Nemeth RJ (1994) Social sources of family contributions: Giving patterns in the Reformed Church in America. Review of Religious Research 36(2): 207-217.

Lunn J, Klay R and Douglas A (2001) Relationships among giving, church attendance, and religious belief: The case of the Presbyterian Church (USA). Journal for the Scientific Study of Religion 40(4): 765-775.

Marx K ([1844]1978) Contribution to the critique of Hegel's philosophy of right. In: Tucker RC (ed) The Marx-Engels Reader, $2^{\text {nd }}$ edition. New York: W.W. Norton, 16-25.

Mead LB (1998) Financial Meltdown in the Mainline? Lanham: Rowman \& Littlefield. 
Miller SL (1999) The Symbolic Meaning of Religious Giving. Ph.D. Dissertation, University of Notre Dame, IN.

Miller RJ, Parfet RA and Zech C (2001) The effect of life cycle and parishioner perceptions on average household giving in Catholic parishes. Review of Religious Research 42(3): 313331.

Miller RJ, Parfet RA and Zech C (2002) The impact of stewardship programs on religious giving: An empirical analysis of Catholic parishes. Journal of Ministry Marketing \& Management 7(1): 43-60.

Miller DW (2006) God at Work: The History and Promise of the Faith at Work Movement. New York: Oxford University Press.

Mundey P (2015) American Christianity \& Consumerism: Understanding the Relationship Between Christian Economic Culture and Secular Consumer Culture. PhD Dissertation, University of Notre Dame, IN.

Mundey P (2017) The Prosperity Gospel and the Spirit of Consumerism According to Joel Osteen. Pneuma: The Journal for Pentecostal Studies 39(3): 315-338.

Mundey P, Davidson H and Snell Herzog P (2011) Making money sacred: How two church cultures translate mundane money into distinct sacralized frames of giving. Sociology of Religion 72(3): 303-326.

Nemeth R and Luidens DA (1994) Congregational vs. denominational giving: An analysis of giving patterns in the Presbyterian Church in the United States and the Reformed Church in America. Review of Religious Research 36(2): 111-112.

Notarantonio EM and Quigley CJ (2009) An investigation of the giving behavior of loyal, lapsed, and non-givers to a religious organization. Nonprofit and Voluntary Sector Marketing 14(3): 297-310.

Numrich PD (2016) Space-sharing by religious groups. Practical Matters Journal 9: 10-30.

Olson DVA and Perl P (2001) Variations in strictness and religious commitment within and among five denominations. Journal for the Scientific Study of Religion 40(4): 757-764.

Olson DVA and Perl P (2005) Free and cheap riding in strict, conservative churches. Journal for the Scientific Study of Religion 44(2): 123-142.

Ottoni-Wilhelm M, Brown E, Rooney PM and Steinberg R (2008) The intergenerational transmission of generosity. Journal of Public Economics 92(10-11): 2146-2156.

Partners for Sacred Places (n.d) Sacred Places: The economic halo effect of historic sacred places. Report, Partners for Sacred Places, Philadelphia, PA.

Paxton P (forthcoming) Charitable giving. In: The Nonprofit Sector: A Research Handbook, $3^{\text {rd }}$ edition (eds) Powell WW and Bromley P. Stanford: Stanford University Press.

Peifer JL (2010) The economics and sociology of religious giving: Instrumental rationality or communal bonding? Social Forces 88(4): 1569-1594. 
Perl P and Olson DVA (2000) Religious market share and intensity of church involvement in five denominations. Journal for the Scientific Study of Religion 39(1): 12-31.

Plotinsky AH (1995) From generation to generation: Transmitting the Jewish philanthropic tradition. New Directions for Philanthropic Fundraising 7: 117-132.

Pressley CO (1995) Financial contributions for the kingdom from the elect: Giving patterns in the black church. New Directions for Philanthropic Fundraising 7: 91-100.

Pressley CO and Collier WV (1999) Financing historic black churches. In: Chaves M and Miller SL (eds) Financing American Religion. Lanham: AltaMira, 21-28.

Rexhausen J and Cieslak M (1994) Relationship of parish characteristics to Sunday giving among Catholics in the archdiocese of Cincinnati. Review of Religious Research 36(2): 218-229.

Ronsvalle JL and Ronsvalle S (1996) The end of benevolence? Alarming trends in church giving. Christian Century 113:1010-1014.

Ronsvalle JL and Ronsvalle S (2018). The State of Church Giving through 2016: What Do Denominational Leaders Want to Do with \$368 Billion More a Year? Champaign: Empty Tomb, Inc.

Roozen D (2011a) Holy toll: The impact of the 2008 recession on American congregations. Report, Hartford Institute for Religious Research, Hartford, CT.

Roozen D (2011b) A decade of change in American congregations: 2000-2010. Report, Hartford Institute for Religious Research, Hartford, CT.

Roozen D (2016) American congregations 2015: Thriving and surviving. Report, Hartford Institute for Religious Research, Hartford, CT.

Rosborough J (2015) A theory of congregational giving. Journal of Public Economic Theory 17(2): 270-295.

Ruger A (1999) Financing protestant theological schools. In: Chaves M and Miller SL (eds) Financing American Religion. Lanham: AltaMira, 111-118.

Scharffs BG (2007) Towards a framework for understanding charitable and economic activities of churches: The U.S. example. Religious Studies Review 1(4): 61-74.

Scheitle C and Finke R (2008) Maximizing congregational resources: Selection versus production. Social Science Research 37(3): 815-827.

Smith C, Emerson MO and Snell P (2008) Passing the Plate: Why American Christians Don't Give Away More Money. New York: Oxford University Press.

Smith C and Davidson H (2014) The Paradox of Generosity: Giving We Receive, Grasping We Lose. New York: Oxford University Press.

Snell Herzog P and Mitchell S (2016) Intergenerational transmission of religious giving: Instilling giving habits across the life course. Religions 7(7): 1-20.

Snell Herzog P and Price H (2016) American Generosity: Who Gives \& Why. New York: Oxford University Press. 
Steensland B and Hemphill A (2016) Religious giving: Patterns, data, and prospects. Report, Giving USA Foundation, the Lilly Family School of Philanthropy, and the Lake Institute on Faith and Giving, Indianapolis, IN.

Starks B and Smith C (n.d.) Unleashing Catholic Generosity: Explaining the Catholic Giving Gap in the United States. Report, University of Notre Dame Institute for Church Life.

Throop JR (2007) Electronic giving and traditional tithing. The Clergy Journal 83(9): 26.

Vaidyanathan B (2013) Living in a secular age: Work, lifestyle, and religion in Bangalore and Dubai. PhD dissertation, University of Notre Dame, IN.

Vaidyanathan B and Snell P (2011) Motivations for and obstacles to religious financial giving. Sociology of Religion 72(2): 189-214.

Vallet R and Zech C (eds) (1995) The Mainline Church's Funding Crisis. Grand Rapids: William B. Eerdmans Publishing.

Weber M ([1930] 2005) The Protestant Ethic and the Spirit of Capitalism. New York: Routledge.

Whitehead AL (2010) Financial commitment within federations of small groups: The effect of cell-based congregational structure on individual giving. Journal for the Scientific Study of Religion 49(4): 640-656.

Whitney RL (2010) An investigation of the relationship between community connectedness and congregational spiritual vitality. PhD dissertation, Andrews University, MI.

Wood RL and Fulton BR (2015) A Shared Future: Faith-based Organizing for Racial Equity and Ethical Democracy. Chicago: University of Chicago Press.

Woolever C and Bruce D (2002) A Field Guide to U.S. Congregations: Who's Going Where and Why. Louisville: Westminster John Knox Press.

Woolever C and Bruce D (2010) A Field Guide to U.S. Congregations: Who's Going Where and Why, $2^{\text {nd }}$ edition. Louisville: Westminster John Knox Press.

Wuthnow R (1994) God and Mammon in America. New York: The Free Press.

Wuthnow R (ed) (1995) Rethinking Materialism: Perspectives on the Spiritual Dimension of Economic Behavior. Grand Rapids: William B. Eerdmans.

Wuthnow R (1997) The Crisis in the Churches: Spiritual Malaise, Fiscal Woe. New York: Oxford University Press.

Wuthnow R (2009) Boundless Faith: The Global Outreach of American Churches. Berkley: University of California Press.

Zaleski PA and Zech CE (1992) Determinants of contributions to religious organizations. American Journal of Economics and Sociology 51(4): 459-472.

Zech CE (2000) Why Catholics Don't Give... And What Can be Done about it. Huntington: Our Sunday Visitor Publishing. 
Zech CE, Gauier ML, Gray MM, Wiggins J, Gaunt TP (2017) Catholic Parishes of the $21^{\text {st }}$ Century. New York: Oxford University Press.

\section{Author's Biographie}

Peter MUNDEY is a Research Associate at the University of Oklahoma Health Sciences Center. His research focusses on religious giving, consumerism, and economic evaluation. He previously worked as a Research Fellow at the Lake Institute on Faith and Giving. Address: University of Oklahoma Health Sciences Center, 940 NE 13th Street, 4th Floor Nicholson Tower, Suite 4900, Oklahoma City OK 73104, USA Email:peter-mundey@ouhsc.edu

David KING is the Director of Lake Institute on Faith and Giving and an Assistant Professor of Philanthropic Studies at the Indiana University Lilly Family School of Philanthropy. His research investigates how the religious identity of faith-based nonprofits shapes their motivations, rhetoric, and practice. He is co-PI for the National Study of Congregations' Economic Practices.

Address: University Hall, Suite 3000, 301 University Boulevard

Indianapolis, IN 46202

Email: kingdp@iupui.edu

Brad R FULTON is an Assistant Professor at Indiana University in the School of Public and Environmental Affairs. His research draws on organizational theory and network analysis to examine the social, political, and economic impact of faith-based and secular organizations. He is co-PI for the National Study of Congregations' Economic Practices.

Address: 1315 E. $10^{\text {th }}$ St., Bloomington, IN 47405

Email: fulton@indiana.edu 